\title{
Digital Quran Applications on Smart Phones and Tablets: A Study of the Foundation Programme Students
}

\author{
Engku Ahmad Zaki Engku Alwi ${ }^{1}$, Norazmi Anas ${ }^{2}$, Mohd. Syahril Ibrahim ${ }^{3}$, Ahmad Fadhir Mat Dahan ${ }^{4}$ \& \\ Zuriani Yaacob ${ }^{5}$ \\ ${ }^{1}$ Faculty of Contemporary Islamic Studies, Universiti Sultan Zainal Abidin (UniSZA), Terengganu, Malaysia \\ 2 Academy of Contemporary Islamic Studies, Universiti Teknologi MARA Perak, Tapah Campus, Perak, \\ Malaysia \\ ${ }^{3}$ Faculty of Law, Universiti Teknologi MARA Cawangan Negeri Sembilan, Negeri Sembilan, Malaysia \\ ${ }^{4}$ Academy of Contemporary Islamic Studies, Universiti Teknologi MARA Pahang, Jengka Campus, Malaysia \\ ${ }^{5}$ Faculty of Education (TESL), UniversitiTeknologi MARA Pahang, Kuantan Campus, Pahang, Malaysia \\ Correspondence: Engku Ahmad Zaki Engku Alwi, Faculty of Contemporary Islamic Studies, Universiti Sultan \\ Zainal Abidin (UniSZA), Gong Badak Campus, 21300 Kuala Terengganu, Terengganu, Malaysia. Tel: \\ 60-12-6013693. E-mail: drkuzaki@unisza.edu.my
}

Received: June 14, 2014 Accepted: June 19, 2014 Online Published: July 11, 2014

doi:10.5539/ass.v10n15p212 URL: http://dx.doi.org/10.5539/ass.v10n15p212

\begin{abstract}
This study aimed to investigate the students' interest level and tendency towards reciting Quran using smart phones and tablets amongst 230 Muslim students of Foundation Programme at UiTM Kuantan Campus, Malaysia semester 2012/2013. The main instrument utilized in this study was a questionnaire while data analysis was accomplished using descriptive statistics of SPSS version 20. Based on the analysis, it was indicated that the students' interest of reciting Quran was at a good level. However, 32.6\% to $53.0 \%$ of them were not really sure about the rules involved when using digital Quran applications stored on the devices. These were among the primary concerns of the present study. Therefore, issues related to Islamic jurisprudence were clarified so that the students would become aware to take necessary steps in compliance with the religious laws when using such devices.
\end{abstract}

Keywords: Quran, Islam, UiTM Kuantan Campus, smart phones and tablets

\section{Introduction}

According to Khan \& Alginahi (2013), the development of information and communication technology (ICT) is growing rapidly in today's modern world and thus, almost all information can be obtained via the Internet. The Internet facilities are acknowledged as an important means for humans to communicate faster and easier such as sending and receiving emails, uploading pictures, downloading songs or dealing with other contents. Interestingly, most of these activities are done using multiple mobile devices available in the market nowadays such as smart phones, iPads, tablets, laptops and other personal digital assistants. It is apparent that digital age has revolutionized the world of communication and changed how humans connect to the world. Without a doubt, it affects the economic growth and humans' living standard in many areas. Razaly et al. (2010) discovered that due to the presence of mobile phones and smart technology particularly among rural communities, people are given wide chances for better Internet access.

Meanwhile, Elhadj (2010) asserts that the Internet technology and innovation have also affected Islamic civilization so profoundly. The progress seems inevitable in many aspects of human life; particularly in the spread of Islamic teachings whereby such innovation has become an educational tool to teach about the religion. Therefore, digital Quran applications on smart phones and tablets are very strong evidence that Islamic teachings are expanding in line with current technology. The holy Quran is the scripture of Islam revealed by Allah to Prophet Muhammad (pbuh) through the mediation of the angel Gabriel (Jibril) for more than 14 centuries ago. Traditionally, Muslims often recite the Quran which was written by the companions of the Prophet in a form of hard copy known as Al-Mushaf (Elhadj, 2010). Nevertheless, with the emergence of smart technologies such as smart phones, tablets and other digital applications, reading Quran has been made easy particularly among 
Muslim users. This is apparent when many Muslims nowadays have started using this Internet facility for the purpose of online Quran tutorials such as for learning, translating, memorizing and reciting the verses (Muhammad et al., 2012).

Therefore, this study presented an investigation of understanding Foundation Programme students at UiTM Pahang, Kuantan Campus, Malaysia pertaining to the recitation of digital Quran. In addition, it also examined the students' tendency to use digital Quran applications in their daily life.

- To investigate the interest of Quran recitation among students of Foundation Programme at UiTM Pahang, Kuantan Campus, Malaysia.

- To examine the tendency of Quran recitation using smart phones and tablets amongst students of Foundation Programme at UiTM Pahang, Kuantan Campus, Malaysia.

\subsection{Literature Review}

According to 'Ismail \& Mohd. Azrul Azlen (2009), reciting the Quran is one of the best good deeds a Muslim can do. It aims to increase the level of love and devotion to Allah, the Almighty Creator. In addition, the Quran should be taken as the core and primary source underlying all aspects of human life (Engku Ahmad Zaki, 2010). Yet, certain etiquette should be emphasized when reading the Quran as it is the word of God. This is clear when a believer recites the Quran; he should adhere to the following manners:

- Taking formal ablutions (wudhu').

- Brushing the teeth using ordinary toothbrush or toothstick (siwak).

- Facing the direction of prayer (qiblah).

- Reading in a quiet and clean place.

However, another pertinent question may arise. If the Quran is recited using digital gadgets; would the manners or ethics mentioned earlier be applied? Indeed, it is worthy to note that modern technology is meant to enhance and improve the quality of human life. In terms of ethics, treating digital Quran is the same as the Qur'an in the form of mushaf / mashaf. Meanwhile, the question may come in from the point of touching the holy book. Commenting on the subject, majority of the Muslim scholars (Jumhur 'ulama) agree that those in the state of major and minor impurities are prohibited (haram) to touch the Quran. Yet, some classical Islamic jurists ('ulama) believe that holding the Quran without ablution is permissible. Under these circumstances, it is apparent that holding to the majority opinions is better than to the minority.

Similarly, the debate also focuses on the rules of holding smart phones, tablets or modern gadgets containing Quranic verses. In such instance, the most authentic opinion is that holding the digital Quran is not included in the above rules as it is not the mushaf (Quran). In fact, it is merely a software application played by certain tools and this also explains the position of compact discs (CDs), digital video discs (DVDs) cassettes and videos in which containing the holy verses of Quran. Hence, it is quite understandable that holding a modern portable device with digital Quran installed on it without ablution is thus, permissible.

Besides, carrying the device into the toilet is allowed provided that the screen does not display the Quranic verses and the recitation is not played. Nonetheless, reciting Quran in the toilet or any dirty place is completely forbidden as it is considered an insult to the Quran (Soal Jawab: Adab membaca Al-Quran mobile, 2013). In many societies these days, modern technology applications have become more and more popular and significantly affected humans' ability. Similarly, the use of high-tech equipment among Muslims can actually add value in their life provided the technology is manipulated accordingly. This includes reciting the Quran on smart phones, tablets and other portable devices. Therefore, the issues emerged concerning Islamic jurisprudence specifically on the rules of holding these modern gadgets containing Quranic verses and its equality to reading the mushaf / mashaf (Quran) itself.

\section{Methodology}

The present study used questionnaires to obtain data from 230 Muslim students of UiTM Pahang Kuantan Campus, Malaysia semester 2012/2013. This involved two Foundation Programmes offered at this university namely Law and TESL (Teaching English as a Second Language).

\subsection{Measurement}

The questionnaire consisted of three parts i.e. A, B and C. Part A was designed to deal with demographic profile of respondents involving three items; Sex (A1), Race (A2) and Programme (A3). Part B attempted to obtain specific information regarding the interest level of reciting Quran among the respondents and it comprised of ten 
items (B1-B10). This section used a dichotomous scale of "Yes" or "No". Meanwhile, Part C was directed to collect the data related to the tendency of respondents using smart phones and tablets to recite the Quran. It involved ten items $(\mathrm{C} 1-\mathrm{C} 10)$ and Likert scale was used indicating five points; $1=$ Strongly Disagree, $2=$ Disagree, $3=$ Not Sure, $4=$ Agree and $5=$ Strongly Agree.

2.1.1 Items of Questionnaire for Quran Recitation Interest among Respondents (Part B)

1. You do not know how to recite the Quran.

2. Parents often recite the Quran at home.

3. Parents always remind you to always recite the Quran.

4. You recite the Quran every day.

5. You recite the Quran after the obligatory prayers.

6. You own the mushaf (Quran) itself.

7. Peers/classmates often invite you to recite the Quran together.

8. You feel calm after reciting the Quran.

9. Lecturer(s) of Islamic Studies guide(s) you in reciting the Quran properly.

10. The course contents of Islamic Studies at the university are more than sufficient to guide you to be able to recite the Quran skilfully.

2.1.2 Items of Questionnaire for Digital Quran Applications among Respondents (Part C)

1. Smart phones and tablets are highly beneficial for students.

2. You need to have digital Quran applications on smart phones and tablets.

3. You regularly recite the Quran on smart phones and tablets.

4. Digital Quran applications on smart phones and tablets have encouraged you to recite the Quran more frequently.

5. You are aware of the rules when reciting the Quran on smart phones and tablets.

6. Reciting the Quran on smart phones and tablets is the same as reading the mushaf (Quran) itself.

7. Smart phones and tablets containing the applications of digital Quran are not allowed to be carried into the toilet.

8. You need to take ablution before reciting Quran on smart phones and tablets.

9. You believe that the content of digital Quran applications stored on smart phones and tablets are the same as the mushaf (Quran) itself.

10. Modern society increasingly recites digital Quran on smart phones and tablets compared to mushaf (Quran) itself.

\subsection{Statistical Techniques}

Today, the use of specific computer software to analyze research data is gaining popularity and undeniably it is an effective alternative in data analysis. Sulaiman (2009) and Aryet al. (2010) point out that Statistical Package for the Social Sciences (SPSS) is the most frequently and widely used software in the field of education when analyzing the descriptive data. Therefore, the researchers utilized SPSS software version 20 in order to analyze the data collected. In addition, Piaw (2006) reports that, descriptive statistics are used to describe the statistical characteristics of the variable / variables using indicators such as mean, median, mode, standard deviation, normal distribution and $\mathrm{Z}$ scores. 


\section{Result}

Table 1. Mean and percentage of Quran recitation interest among respondents

\begin{tabular}{cccc}
\hline \multirow{2}{*}{ Items } & Mean & \multicolumn{2}{c}{ Percentage (\%) } \\
\cline { 3 - 4 } & & Yes & No \\
\hline B01 & 1.94 & 6.1 & 93.9 \\
B02 & 1.23 & 77.4 & 22.6 \\
B03 & 1.14 & 85.7 & 14.3 \\
B04 & 1.77 & 23.5 & 76.5 \\
B05 & 1.64 & 35.7 & 64.3 \\
B06 & 1.13 & 87.4 & 12.6 \\
B07 & 1.89 & 10.9 & 89.1 \\
B08 & 1.01 & 99.1 & 0.9 \\
B09 & 1.19 & 81.3 & 18.7 \\
B10 & 1.76 & 24.3 & 75.7 \\
\hline
\end{tabular}

Sources: Survey

Table 2. Mean and percentage of digital Quran applications among the respondents

\begin{tabular}{ccccccc}
\hline \multirow{2}{*}{ Items } & \multirow{2}{*}{ Mean } & \multicolumn{5}{c}{ Percentage (\%) } \\
\cline { 3 - 7 } & & Strongly Disagree & Disagree & Not Sure & Agree & Strongly Agree \\
\hline C01 & 4.42 & 0.4 & 1.3 & 7.0 & 38.7 & 52.6 \\
C02 & 4.38 & 1.3 & 3.5 & 7.4 & 31.7 & 56.1 \\
C03 & 3.04 & 8.3 & 24.3 & 32.6 & 24.8 & 10.0 \\
C04 & 3.27 & 4.3 & 18.7 & 32.6 & 34.3 & 10.0 \\
C05 & 3.13 & 3.0 & 20.4 & 43.9 & 25.7 & 7.0 \\
C06 & 3.03 & 6.1 & 21.7 & 42.6 & 22.6 & 7.0 \\
C07 & 3.16 & 5.7 & 17.4 & 49.1 & 10.9 & 17.0 \\
C08 & 2.82 & 8.7 & 22.2 & 53.0 & 10.4 & 5.7 \\
C09 & 3.10 & 5.7 & 13.9 & 50.8 & 23.9 & 5.7 \\
C10 & 3.64 & 1.7 & 7.8 & 33.0 & 39.6 & 17.8 \\
\hline S0unyyyyy
\end{tabular}

Sources: Survey

\section{Discussion}

Table 1 shows the mean and percentage of 10 items related to Quran reading interest among the students of Foundation Law and TESL at UiTM Pahang, Kuantan Campus, Malaysia semester 2012/2013. The mean value was between 1.01 and 1.94 and this suggested that the respondents' reading interest were positive. Based on Table 1 as well, majority of the respondents generally knew how to recite the Quran. In addition, parents were key drivers for the respondents to recite the holy book. This is based on the high percentage of respondents who agreed with items 2 and 3, which was between $77.4 \%$ and $85.7 \%$. Even so, $76.5 \%$ of respondents did not recite the Quran every day and only $64.3 \%$ of them practiced reading the Quran after the obligatory prayers. As a whole, it was found that reading the Quran in collaborative manner was not fully practiced. Besides, peers or classmates did not play a role to encourage such practice. However, $99.1 \%$ of the respondents reported that they felt calm after reciting Quranic verses. Next, $81.3 \%$ of the respondents agreed with item 9 that the lecturer(s) of Islamic Studies guided them in reading the Quran properly. Yet, $75.7 \%$ of the respondents stated that the course contents of Islamic Studies were not sufficient to assist them to read the Quran skilfully.

Table 2 provides a summary of mean and percentage values of 10 items related to digital Quran applications among the students of Foundation Programme at UiTM Pahang, Kuantan Campus, Malaysia semester 2012/2013. The mean value obtained was between 2.82 and 4.42. Based on Table 2 as well, a total of $91.3 \%$ respondents agreed and strongly agreed with item 1 i.e. smart phones and tablets are highly beneficial for students. For item 2, majority of the respondents (87.8\%) agreed and strongly agreed that digital Quran applications must be uploaded onto the smart phones and tablets. As for items 3 to 10 , it was found that the percentage of the respondents answering "Not Sure" was rather high i.e. between $32.6 \%$ and 53\%. This indicated that the respondents were not 
clear or rather not aware about the issues raised in Part $\mathrm{C}$ of this questionnaire. In addition to that, over $50 \%$ of the respondents answered "Not Sure" for items 8 and 9. It was apparent that the respondents were not fully aware about the rules of using digital Quran applications on their smart phones and tablets.

In general, the interest level of reciting Quran amongst the students of Foundation Programme at UiTM Pahang, Kuantan Campus, Malaysia was positive. However, it was obvious that they did not really practice reading it in their daily life be it at home or campus. Even so, digital Quran applications on smart phones and tablets were found useful to most students. Additionally, it was considered as one of the convenient ways for them to improve their Quran recitation skills. However, students should enhance their knowledge about the rules involved when reciting the Quran, particularly on modern mobile devices. This is important so that they can maximize its functions in line with the true teachings of Islam.

\section{References}

Ary, D., Jacobs, L. C., \& Sorensen, C. (2010). Introduction to research in education. Australia: Wadsworth Cengage Learning.

Elhadj, Y. O. M. (2010). E-halagat: An e-learning system for teaching the holy Quran. Turkish Online Journal of Educational Technology, 9(1), 54-61.

Engku Ahmad Zaki, E. A. (2010). Apa itu Islam? Menerangkan Islam secara mudah dan lengkap. Selangor: PTS Islamika Sdn. Bhd.

Ismail, K., \& Mohd. Azrul Azlen, A. H. (2009). Indahnya hidup bersyariat, modul fardhu ain diri, keluarga dan masyarakat sepanjang hayat. Kuala Lumpur: Telaga Biru Sdn. Bhd.

Khan, M. K., \& Alginahi, Y. M. (2013). The holy Quran digitization: Challenges and concerns. Life Science Journal, 10(2).

Muhammad, A., UlQayyum, Z., Waqar, M. M., Tanveer, S., Martinez-Enriquez, A. M., \& Syed, A. Z. (2012). E-hafiz: Intelligent system to help Muslims in recitation and memorization of Quran. Life Science Journal-Acta Zhengzhou University Overseas Edition, 9(1), 534-541.

Piaw, C. Y. (2006). Kaedah penyelidikan: buku 1. Kuala Lumpur: McGraw Hill.

Razaly, F., Ajizan, N. H., Saad, S. M., Yaacob, M. S., Zain, M. Z. M., \& Hussein, M. (2010). User friendly system for the visually impaired in learning Al-Quran. WSEAS Transactions on Systems, 9(6), 659-668.

Soal Jawab: Adab membaca Al-Quran mobile. Retrieved July 13, 2013, from http://ustazlove.com/blog/2011/08/ soal-jawab-adab-membaca-al-quran-mobile

Sulaiman, S. (2009). Research methods for the social sciences: made simple. Klang, Selangor: DSS Publishing Enterprise.

\section{Copyrights}

Copyright for this article is retained by the author(s), with first publication rights granted to the journal.

This is an open-access article distributed under the terms and conditions of the Creative Commons Attribution license (http://creativecommons.org/licenses/by/3.0/). 